\title{
National systems of education as a factor of socio-economic development of the world countries under the conditions of digital society
}

\author{
Nina O. Voskresenskaya ${ }^{1 *}$, Ludmila A. Murav'eva ${ }^{1}$, and Ainur D. Kurmanalieva ${ }^{2}$ \\ ${ }^{1}$ Financial University under the Government of the Russian Federation, Department of Humanities, \\ Moscow, Russia \\ ${ }^{2}$ Al-Farabi Kazakh National University, Department of Philosophy and Religious Studies, Almaty, \\ Republic of Kazakhstan
}

\begin{abstract}
This work verifies the hypothesis, according to which the systems of upbringing and education, historically developed by different nations, are the factor determining the pattern of their socio-economic evolution and the level of life quality of population. In order to verify the hypothesis, two groups of world countries were highlighted with opposite performances of economic and humanitarian development. Comparative analysis of basic socio-economic parameters in these groups of countries as well as their adopted systems of upbringing and education revealed serious distinctions. For countries with a high level of economic and human development, the most important goal of the educational process is the purposeful development of the intellectual, emotional, and volitional characteristics of children; the task of acquiring specific work skills in early childhood is not set. In the courtiers with low level of development, the situation is opposite. The final conclusion is that the level of economic and human development of people is directly related with their national educational principles and traditions. It is possible to develop an educational model, optimum for successful national development, and to create required conditions for its distribution in the world using advanced digital technologies.
\end{abstract}

Keywords: Africa, education, developed countries, economy.

\section{Introduction}

The world history demonstrates that development of nations is not homogeneous; the heterogeneity is manifested in all life spheres of society. There are no well-recognized and accurate criteria for an objective evaluation of the non-uniformity in the areas of culture, arts, religion, of what is good and what is bad for society and state. Though, the situation is more definite with respect to non-uniformity in economic development: a society with higher life quality is more preferable in comparison with a poor society.

The question of what determines the wealth of society has attracted the attention of thinkers during overall world history. It is still relevant nowadays [1]. Different researchers

\footnotetext{
*Corresponding author: novoskresenskaya@,fa.ru
} 
approach the problem differently: nation wealth is attributed to natural factor, facts of national history, quality of established national institutions. Some researchers highlight education: John Locke claimed that national wellbeing depended on correct education of children [2:398]. The research hypothesis is also in that the economic development of nation strongly depends on national educational systems. Under conditions of digital society, the role of this factor will increase.

\section{Methods}

The hypothesis was examined by comparison of basic properties of educational systems adopted in the countries with polar levels of economic and human development. This article applied historic-typological, historic-comparative, historic-system methods [3]. The reference base included statistics of UN and IMF for GDP and GDP per capita, The UN Human Development Index. These classifications being combined [4-7] allowed revealing two polar groups of countries: developed rich and developing poor.

\section{Results}

The developed countries, such as Australia, Great Britain, Germany, Canada, the USA, France, Switzerland, are characterized by significant role of science-intensive productions and hi-tech industries. The level of production corresponds to consumer demand; $70-80 \%$ of GDP is produced in services. National currencies are freely convertible, the inflation level is low. These countries are deeply integrated into world market. Successful development is supported by steady investment climate, political stability, specificity of administrative activity not interfering with business, low level of criminality and corruption, high level of education and orderliness in combination with their high entrepreneurial activity. These countries are characterized by the highest life expectancy in the world [8].

The poorest countries in the world, such as Burundi, Guinea, Zimbabwe, Malawi, Liberia, Niger, Ruanda, Central African Republic, Eritrea, are also characterized by common properties. Agriculture, accumulating up to $95 \%$ of population, cannot provide citizens with food products. In some countries, the economic vulnerability is caused by droughts and poor soils. In other countries, optimum agricultural climatic conditions allow producing and exporting goods demanded at world market. However, the production scale is not sufficient neither for export nor for internal consumption. Some of these countries have huge mineral resources, which creates perfect conditions for industry development, though, their actual level is very low. The most acute problems of these countries are prolonged civil wars, ethnic and religious conflicts, armed collisions with neighboring countries [9], political instability, corrupt and inefficient authorities [10], low level of democracy [11], high crime rate, kidnapping [12], high level of gender inequality [13], the highest in the world child mortality rate and the lowest rate of life expectancy. In accordance with UN programs, these countries have simplified access to global markets and favorable conditions for obtaining credit, though, this does not help them to improve socio-economic situation.

Thus, the types of socio-economic development in these two groups of countries are significantly different. How different are the educational systems adopted in these countries? Let us define education as a targeted impact on children aiming at their training for performance of various personal and social meaningful tasks, which combines elements of upbringing and education.

The educational systems of Western countries were formed under similar historic conditions and are characterized by similar basic properties. The main purpose was fostering of ability for self-control, which started to be formed in early childhood: an adult person 
cannot be improved [14: 446]. However, a person during the life course can obtain certain skills and habits, therefore, mastery of practical skills by children was considered as an important but minor task. A person, incapable of self-control and self-constraint, cannot consider for interests of other people, which leads to social conflicts. Thus, the basics of morality and correct attitude to society should be established in early childhood [15]. Children are taught skills of team thinking and behavior, they are taught to be socially active. The most important purpose is to develop children's intelligence, their curiosity, cognitive abilities, imagination. Individual features of children are taken into account, though, without discrimination in terms of gender or social principle. The time devoted to children is significant; the teacher's personality is also important: only educated people can educate a person. In this way, children are taught self-discipline, entrepreneurial spirit, self-confidence, inner freedom, orderliness, to be personally responsible for their actions, and ready for teamwork. Exactly these personal features promote successful economic development of country in whole.

Fostering in the poorest countries of the world is based on parents' desire to reduce as maximum as possible the period of helpless infancy. One-year-old children are often left alone without adults' care: while searching for food, parents usually neither have opportunity nor habit to pay attention to children's needs. Children were supposed to participate in working life from the early childhood, which required to transfer labor skills to them as early as possible [16]. Common labor areas for five- to six-year-old boys in African tropical countries are agriculture, crafts, trading. Girls are trained for future motherhood. Herewith, a woman is considered as an appendage of a man, completely obeying him in domestic and sexual affairs [13]. Many children in these countries do not attend school despite the adopted laws about obligatory education. The literacy level is about $30-75 \%$; the access to higher education is restricted. The features of education are comprised of numerous regulations mandatory for execution, based on superstitions and omens; they are not analyzed and explained to children, adults just demand to obey to them. Therefore, intellectual and moral upbringing was replaced with labor education, practical learning of children based on the principle of visibility and imitation of known patterns. However, even successful mastering of practical skills by children in the case of insufficient attention to development of their character, cognitive abilities, team working decreases efficiency of education in modern world. This educational model allowed society to survive, though, while preserving traditional pedagogic methods and transferring them to new generations, prevented development. The results were reproduction of traditional patterns of economic behavior. This educational system was unable to promote successful humanitarian and economic policy, which stipulated low efficiency of national economies of these countries.

\section{Conclusion}

Economic success of a country depends not only on its natural resources and available benefits but also on good management and rationally arranged policy, which should be necessarily based on efficient system of education. Educational systems in poor and rich countries are based on different principles, their economic efficiency is different, the Western model is characterized by obvious advantages. In the existing digital society with high level of mobility and information openness, the educational systems are borrowed faster than before. Educational systems of economically strong countries with high probability will be demanded in other countries and replace local inefficient educational models. 


\section{Acknowledgments}

This work was supported by the Scientific Foundation of Financial University.

\section{References}

1. D. Acemoglu, J.A. Robinson, Why nations fail: The origins of power, prosperity, and poverty (Crown Publishers, USA, 2012)

2. V.N. Baliazin (Ed.), Mudrost tysyacheletiy. Entsiklopediya [The wisdom of the millennia. Encyclopedia] (Olma-Press, Moscow, 2005)

3. I.D. Kovalchenko, Metody istoricheskogo issledovaniya [Historical research methods] (Nauka, Moscow, 2003)

4. World Bank, GDP (current US\$). World Bank national accounts data, and OECD National Accounts data files (n.d.). Accessed on: December 20, 2020. [Online]. Available: https://data.worldbank.org/indicator/NY.GDP.MKTP.CD

5. World Bank, GDP per capita, PPP (current international \$). International comparison program, World Development Indicators database, Eurostat-OECD PPP Programme (n.d.). Accessed on: December 20, 2020. [Online]. Available: https://data.worldbank.org/indicator/NY.GDP.PCAP.PP.CD

6. UNDP, Human Development Report 2019. Beyond income, beyond averages, beyond today: inequalities in human development in the 21 st century (United Nations Development Programme, New York, 2019). Accessed on: December 20, 2020. [Online]. Available: http://hdr.undp.org/en/content/human-development-report-2019

7. International Monetary Fund, Report for selected countries and subjects: october 2020 (2020). Accessed on: December 20, 2020. [Online]. Available: https://www.imf.org/en/Publications/WEO/weo-database/2020/October/weo-report

8. Investlab. Top 20 countries that live richer than the rest (2020). Accessed on: December 20, 2020. [Online]. Available: https://invlab.ru/ekonomika/samye-bogatyestrany-mira/

9. C.R. Cook, SAGE Open, 3(3), 1-13 (2013). https://doi.org/10.1177/2158244013495051

10. B. Gumah, M.A. Aziabah, SAGE Open, 10(2), 1-10 (2020). https://doi.org/10.1177/2158244020935900

11. G.E. Oboh, SAGE Open, 6(3), 1-10 (2016). https://doi.org/10.1177/2158244016666886

12. L. Mafu, SAGE Open, 9(1), 1-10 (2019). https://doi.org/10.1177/2158244019828849

13. M.-A. Sossou, SAGE Open, 1(1), 1-9 (2011). https://doi.org/10.1177/2158244011410715

14. I. Kant, Kant on education (Ueber paedagogik), trans. Annette Churton (D.C. Heath and Co., Boston, 1900)

15. N.A. Orekhovskaya, A.G. Tyurikov, P.V. Razov, M.V. Kibakin, N.I. Kiseleva, Eurasian Journal of Analytical Chemistry, 12(7b), 1283-1289 (2017)

16. N.A. Kochneva, Traditsionnaya sistema vospitaniya i obrazovaniya u narodov Tropicheskoy Afriki [Traditional system of upbringing and education among the peoples of Tropical Africa], in R.N. Ismagilov (eds.), Traditsionnyye kul'tury afrikanskikh narodov: proshloye i nastoyashcheye [Traditional cultures of African peoples: past and present] (Vostochnaya literatura, RAS, Moscow, 2000) 